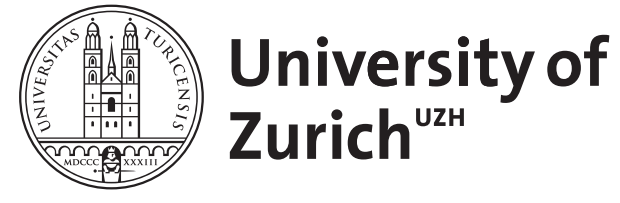

\title{
An early description of drosophila
}

Peyer, B

DOI: https://doi.org/10.1093/oxfordjournals.jhered.a105728

Posted at the Zurich Open Repository and Archive, University of Zurich ZORA URL: https://doi.org/10.5167/uzh-155626

Journal Article

Published Version

Originally published at:

Peyer, B (1947). An early description of drosophila. Journal of Heredity, 38(7):195-199.

DOI: https://doi.org/10.1093/oxfordjournals.jhered.a105728 

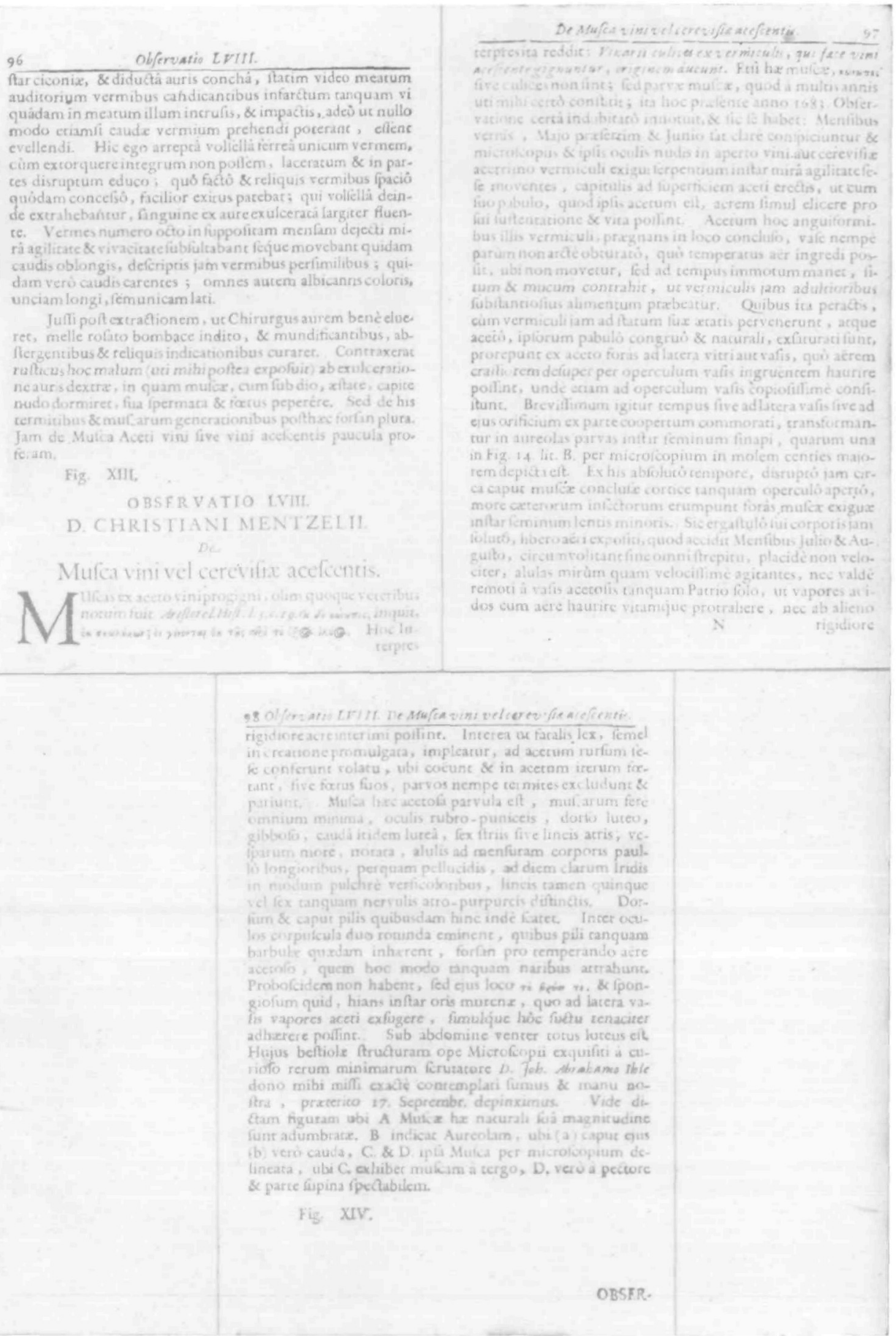

\section{GENESIS OF GENETICS-FROM LIGHT WINES AND BEER}

Figure 1

Tiny fies, with six dark stripes on a yellow abdomen were described in 1683 by Christian Mentzel. The account was published in Nuremberg in the following year. 


\title{
AN EARLY DESCRIPTION OF DROSOPHILA
}

\author{
B. Peyer \\ Zoologisches Museum der Universitat Zïrich
}

$\mathrm{R}^{\mathrm{n}}$ ECENT research has practically made Drosophila the domestic animal of biology. Therefore, it may be justified ta call attention to one of the earliest manuscripts pertaining to Drosophila yet discovered, a description of the fly written by Christian Mentzel as early as 1683 and published in the following year in the periodical of the Academia Naturae Curiosorum (Ephemerides, Decuria II, Annus II, Observatio LVIII, Nuremberg 1684)** The paper being written in Latin, the question arose whether to give only a translation or a translation accompanied by the Latin original. The latter, though somewhat complicated, seemed to me preferable because it would have been too difficult a task to render by the translation not only the author's meaning, but at the same time to imitate the stylistic character of the Latin scientific publications of those days.

\section{De musca vini vel cerevisiae acescentis}

Muscas ex aceto vini progigni, olim quoque veteribus notum fuit. Arisioiel. Hist. 1.5 c. 19.

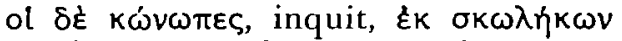

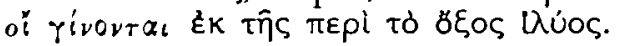
Hoc interpres ita reddit: Vinarii culices ex vermiculis, qui faece vini acescente gignuntur, originem ducunt. Etsi hae muscae $\kappa \omega ́ v \omega \pi \varepsilon \varsigma$ sive culices non $\sin ^{1}$; sed parvae muscac, quod a multis annis uti mihi certo constitit, ita hoc praesente anno 1683. Observatione certa indubitato innotuit et sic se habet:

Mensibus vernis, Majo praesertim et Junio sat clare conspiciuntur et microscopiis et ipsis oculis nudis in aperto vini aut cerevisiae acerrimo $^{2}$ vermiculi exigui serpentium instar mira agilitate ${ }^{3}$ sese moventes, capitulis ad superficiem aceti erectis ${ }^{4}$, ut cum suo pabulo, quod ipsis acetum est, aërem simul elicere pro sui sustentatione et vita possint. Acetum hoc anguiformibus illis vermiculis praegnans

\section{On the fly of wine or beer turning sour}

In days past, it has been known to the ancients too that flies arise from vinegar of wine. Aristotle, Historia animalium, book 5, chapter 19 says: "The gnats arise from small worms that originate in the dregs around the vinegar." The translator renders this passage as follows: The vinegar-gnats originate in small worms that proceed from the vincgar dregs. Still, these flies arc no gnats $\dagger$ but litt]e flies. This was clear to. me for many years. In the present year 1683 it has been cstablished beyond any doubt by reliable observation. The facts are these:

In spring-time, especially in May and June, one can see very distinctly by means of the micrcscope and even with the naked eye, small snakelike worms moving with astonishing agility ${ }^{3}$ in open acid of wine or beer $^{2}$. They raise their little heads to the surface of the vinegar for the ford, consisting of vinegar, and the air which are neces-

*Although no entomologist myself, I got acquainted with Mentzel's description of Drosophila by mere chance. For the bicentenary of the Naturforschende Gesellschaft in Zurich. I published a biography of the Swiss physician and naturalist, J. von Muralt. Into one of the plates accompanying Muralt's observations, the editor of the Ephemerides had inserted figures belonging to other observations and among them Mentzel's drawings of Drosophila. Professor E. Hadorn encouraged me to publish this little contribution to the history of natural science and it is to one of his students, H. Burla. that $I$ am indebted for the necessary information about modern researches on Drosophila.-B. P.

$\dagger$ These references are to "Notes" on page 197. 
in loco concluso, vase nempe parum non arcte obturato, quo temperatus aër ingredi possit, ubi non movetur, sed ad tempus immotum manet, situm et mucum contrahit, ut vermiculis jam adultioribus substantiosius alimentum praebeatur. Quibus ita peractis, cum vermiculi jam ad statum suae aetatis pervenerunt, atque aceto, ipsorum pabulo congruo et naturali, exsaturati sunt, prorepunt ex aceto foras ad latera vitri aut vasis, quo aërem crassiorem desuper per operculum vasis ingruentem haurire possint, unde etiam ad operculum vasis copiosissime consistunt. Brevissimum igitur tempus sive ad latera vasis sive ad ejus orificium ex parte coopertum commorati, transformantur in aureolas ${ }^{6}$ parvas instar seminum sinapi, quarum una in Fig. 14 lit. $B$ per microscopium in molem centies $^{\theta}$ majorem depicta est. Ex his absoluto tempore, disrupto jam circa caput muscae conclusae cortice tanquam operculo aperto ${ }^{7}$, more caeterorum insectorum erumpunt foras muscae exiguae instar seminum lentis minoris ${ }^{8}$. Sic ergastulo corporis jam soluto, libero aëri expositi, quod accidit Mensibus Julio et Augusto, circumvolitant sine omni strepitu, placide non velociter, alulas mirum quam velocissime agitantes. nec valde remoti a vasis acetosis tanquam Patrio solo, ut vapores acidos cum aëre haurire vitamque protrahere, nec ab alieno rigidiore aëre interimi possint ${ }^{\theta}$. Interea ut fatalis lex, semel in creatione promulgata ${ }^{10}$, impleatur, ad acetum rursum sese conferunt volatu, ubi coëunt et in acetum iterum foetant, sive foetus suos, parvos nempe termites excludunt et pariunt. Musca haec acetosa parvula est, muscarum fere omnium minima, oculis rubropuniceis, dorso luteo, gibboso ${ }^{11}$, canda itidem lutea, sex striis sive lineis ${ }^{\mathbf{1 2}}$ atris, vesparum more, notata, alulis ad mensuram corporis paulo longioribus, perquam pellacidis, ad diem clarum Iridis in modum pulchre versicoloribos, lineis tamen quinque vel sex tanquam nervulis atro-purpureis ${ }^{\mathbf{1 3}}$ distinctis. Dorsum et caput pilis quibusdam hinc inde scatet. Inter oculos corpuscula duo rotunda ${ }^{14}$ eminent, quibus pili tanquam barbulae inhae- rent, forsan pro temperando aēre acetoso, quem hoc modo tanquam naribus attrahunt. Proboscidem ${ }^{10}$ non habent, sed ejus loco to Bpúov tl et spongiosum quid, hians instar oris murenae, quo ad latera vasis va- sary for the maintenance of life. If this vinegar pregnant with those snakelike little worms is kept in a closed room, that means in a receptacle closed a bit but not tightly, so that some air can enter, and if it is not moved but remains still for a certain time, it develops mud and mucus, so that a more substantial food is provided for the worms which are now mature. When this has been carried out in that way and when the worms have arrived at maturity and are satiated with their convenient and natural food, the vinegar, they creep out of the vinegar to the wall of the glass or receptacle to breathe the thicker air that enters from above through the lid of the receptacle. Therefore they place themselves in great number even on the lid of the receptacle. Having stayed a very short time on the walls of the receptacle or on its halfclosed lid, they are transformed into small chrysalides $^{5}$ of the size of a mustard-seed. One of them, magnified a hundred times by the microscope ${ }^{\theta}$, is shown in Figure 14, letter B. Out of them, after a certain time, break forth in the way of other insects ${ }^{7}$ tinv flies of the size of the seeds of the smaller lentil ${ }^{8}$, the bark arcund the head of the enclosed fly having been broken in the same way that a lid is opened. The jail of their body is disintegrated and they are exposed to the open air. That happens in the months of July and August. They fly about without any noise, softly not quickly, and they move their little wings with astonishing velocity. They do not much venture forth from the vinegarpots, their native soil, thus maintaining their lives by drawing in the vapours of vinegar and thereby protecting themselves against a rougher air ${ }^{\theta}$. Then, in order to fulfill the fateful law proclaimed in the days of creation ${ }^{10}$; they fly back to the vinegar, where they copulate and conceive, bringing forth and emitting into the vinegar their fetus', namely little grubs. This vinegar-fly is very small, more or less the smallest of all flies. Its eyes are purple. The back is yellow and gibbous $^{11}$. The tail also is yellow, signed by six dark wasp-like stripes or lines ${ }^{12}$. The small wings are a little longer than the body and very transparent. In bright day-light they are splendidly iridescent like a rainbow. They are signalized by five or six dark lines like dark purple-coloured ${ }^{13}$ little nerves. Back 


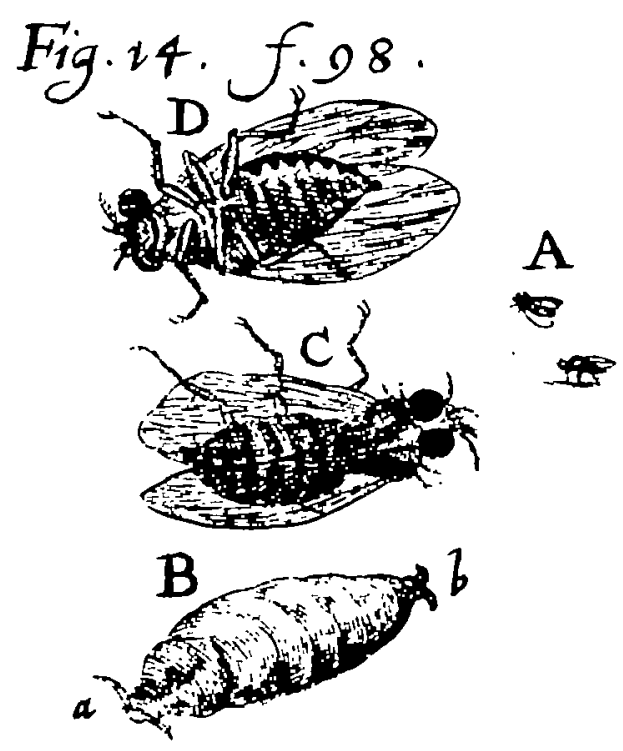

pores aceti exsugere, simulque hoc suctu tenaciter adhaerere possint. Sub abdomine venter totus luteus est. Hujus bestiolae structuram ope Microscopii exquisiti a curioso rerum minimarum scrutatore D. Joh. Abrahamo Ihle ${ }^{1 \theta}$ dono mihi missi exacte contemplati sumus et manu nostra, praeterito 17 . Septembr, depinximus. Vide dictam figuram ubi A Muscac hae naturali sua magnitudine sunt adumbratae. B indicat Aureolam, ubi (a) caput ejus (b) vero cauda, C et D ipsa Musca per microscopium delineata, ubi C. exhibet muscam a tergo $D$. vero a pectore et parte supina spectabilem.

\section{"NO GNATS"}

Figure 2

Mentzel's figure 14 shows enlarged views of his little flies, and of a pupa, correctly labelled as to fore and aft ends. The life-size sketch is an excellent reproduction of Drosophila.

and head are full of certain bristles on both sides. Between the eyes project two little rounded bodies ${ }^{14}$ to which bristles are attached like little beards, perhaps for mitigating the vinegar-air that they draw in in this way as with nostrils. They have no proboscis ${ }^{15}$, but have instead a certain bryon and something spongy yawning like the mouth of a muraena for sucking the vinegar-vapours on the wall of the receptacle and at the same time for sticking firmly to the wall by the act of sucking. Below the abdomen the whole belly is yellow. We did inspect accurately the structure of this little animal by means of an excellent microscope. This instrument has been sent to us as a present from $\mathrm{Mr}$. Joh. Abraham Ihle ${ }^{\mathbf{1 0}}$, that inquisitive scrutineer of objects of small dimensions. Last September $17^{\text {th }}$ we depicted the little animal with our own hand. See the figure mentioned, where in A these flies are outlined natural size. $B$ shows the chrysallis, where (a) means the head and (b) the tail. $C$ and $\mathrm{D}$ are the fly itself delineated through the microscope. $\mathrm{C}$ shows the fly from the back and $D$ from the breast and the ventral side.

\section{Notes}

1 The customary meaning of $\kappa \omega \dot{\nu \omega \pi \varepsilon \varsigma}$ in Greek, culices in Latin, was gnats or mosquitoes. A konopeion, for instance, was a mosquito-net. Quoting Aristotle, the author therefore insists on the fact that the vinegar-fly is no gnat. to me.

2 in aperto vini aut cerevisiac acerrimo:- The exact meaning of this passage is not clear

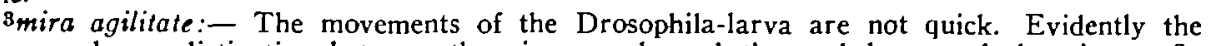
author made no distinction between the vinegar-eels and the real larvae of the vinegar-fly described by him at the same time.

4capitulis ad superficiem aceti erectis:- It is not the head but the hind part with the posterior spiracles that is exposed to the air for breathing. In the drawing of the pupa, the position of the head is correctly indicated.

Gaureolas:- An unsuccessful attempt to Latinize the Greek term Chrysallis used by Pliny. In a previous paper on insects (Ephemerides, Dec. II, Annus I, Obs. 30, 1683), where the vinegar-fly is only briefly mentioned, Mentzel uses the term pupulas for puparia.

${ }_{\text {B }}$ enties majorem:- Ten times linear.

Ttanquam operculo aperto:- The observation is excellent.

8seminum lentis minoris:- Lens culinaris Medicus. The seeds of this plant cultivated from times immemorial differ considerably in size in its numerous subspecies and varieties. The smallest seeds correspond to the comparison. 
Once ab alicno rugdiore ä̈rc interimi possint:- The passage slows that Mentzel did not know the wild species of Drosophila.

10fatalis lex:- Genesis 1, 22. "Be fruitful and multiply." The emphasis of this quotation seems to mark the contrast to Aristotle's doctrine of a yencratio spontanca.

11dorso gibboso:- Probably the contour of the anterior part of the mesonotum in lateral view.

12cauda:- The abdomen.

187crulis atropurpurcis:- The statement seems to be incorrect; see "Discussion" below.

14 corpuscula duo rotunda:- The antennae.

15 proboscidem non habent:- In the modern sense, Drosophila has a proboscis though different from that of the Lepidoptera. What the author describes as bryon ti and spongiosim quid, are parts of the proboscis. Bryon has two significations, that of moss and that of catkins of plants. The comparison seems to rest on the latter meaning. Spongiosum quid unmistakably signifies the oral lobes of the proboscis.

10 Joh. Abraham Ihle:- Friend of Mentzel. He lived at Leipsic. Together with his friend, he had published in the Ephcmerides of the foregoing year, 1683 (Dec. II, Annus I, p. 71) the Observatio de muscis quibusdam ctliciformibus, pedictlosis, grylliformbus et aliis.

\section{Discussion}

As to the question which species of Drosophila may have been described by Mentzel, modern "drosophilosophers" explained to me that in all probability it must have been $D$. inelanogaster; only the outlines of the puparium do not support this interpretation. At any rate, it must have been not a wild species, but a domestic one, from among the palaearctic species melanogaster, simulans, funebris, immigrans and Kuntzei. That the species described by Mentzel may have been extinct or become very rare in the meantime, is not probable. Nearly all the indications given in the description -eyes purple; mesonotum yellow; abdomen yellow with six black bands (females!); wings very transparent and iridescent; belly (comprising the ventral plates of the abdomen) yellow-refer to melanogaster and to simulans. The only passage of the description that does not correspond to any palaearctic species of Drosophila at all is "nervulis atropurpureis." The veination of the wings is always either yellow or brownish yellow in the case of melanogaster, but never purple. The erroneous statement of Mentzel may be due to observation in transmitted light. The published drawings, though showing rather well the general characters. are not sufficient for modern specific determination. In the puparium (Figure $2 B$ ) for instance. the cast mouth armature visible through the pupa-case and common to dipteranymphs is carefully delineated, whilst the outlines of the anterior spiracles are rot rendered accurately enough to permit a determination of the species.

\section{Christian Mentzel, 1622-1701}

The author of this description of Drosophila, Christian Mentzel, was born at Fürstenwalde in Brandenburg, June 22, 1622. He died in Berlin, January 17, 1701. An M.D. of the University of Padua in 1654, a distinguished physician, he became a member of the Acadenia Naturae Curiosorum in 1675. $\mathrm{He}$ is chiefly known by his botanical works, especially by the Index nominum plantarum universalis, Berlin 1682, and by linguistic and historical studies on China. Many of his minor writings have been published as "Observationes" in the Ephemerides; these treat partly of medical questions, partly of various branches of natural history. Nine of them are on insects. An excellent anonymous biography of Mentzel appeared in Ephemerides, Dec. III, Annus VII and VIII, 1702, Appendix p. 193.

Mentzel's description of Drosophila shows the difficulties early entomological workers had to overcome and at the same time the low rates of diffusion of new scientific results. The way in which he treats the problems of respiration proves that he was not yet acquainted with Malpighi's De bombyce, published 1669 , and with the discoveries of Jan Swammerdam. During his studies, Mentzel had seen a good deal of Europe and paid a visit to Holland, but that had 
been long before the beginning of Swammerdam's researches. On the other hand, it must be taken into consideration that Swammerdam's famous Bible of Nature was not published until 17371738 , more than fifty years after its completion. Professional duties did not permit Mentzel to specialize in entomological anatomy and thus vie with the founders of modern entomology. Nevertheless the fact that he did not recoil from investigating, describing and drawing so small an object as Drosophila, aided only by the modest microscopes of those days, is a tribute to his scientific spirit that deserves acknowledgment. As it is not possible to discuss Mentzel's other entomological observations in this short article, the reader is referred to E. C. Cole's History of Comparative Anatomy, London 1944, where they are honorably mentioned.

\section{THE G.I. AT COLLEGE}

\section{An opportunity for Eugenics}

$\mathrm{T}$ $\mathrm{HE}$ present invasion of college campuses by married G.I.'s with their wives and children constitutes a revolution unequalled in the history of American education. In our opinion it furnishes the essential key to the problem of how to promote early marriages and a high birthrate among college students, which thus far has defied the ingenuity of eugenists. At precisely the time of life when they are attending college the students are biologically better fitted for parenthood than they will ever be again. Their youthful idealism untarnished by the sordid competitive struggle for gain. they are under the daily supervision and guidance of adults who are convinced of the need for a eugenic revision of birth-rates. Heretofore the colleges have been hostile to undergraduate marriages, but the G.I. Bill of Rights seems to be rápidly changing this.

At least two schools in the United States are now experimenting with the care of very young children as part of the curriculum in the attempt to give their students experience of real lifethe Daniel Webster High School at Tulsa, Oklahoma, and Iowa State College. Unfortunately the latter-whose undergraduates are old enough to marry and have children-has been unable to obtain funds with which to enlarge their nursery-school facilities so as to take care of the children of the students themselves as well as those of outsiders. This is a typical illustration of the way in which the more socially intelligent members of a society are restrained by the less socially intelligent from carrying out their purposes - a phenomenon particularly menacing when it comes to eugenics since it controls not only the course of the present society but the inborn constitution of coming generations. The true educator. seeking the maximum of academic freedom, finds hinself forced to compromise on vital points by the very society he is seeking to serve. Thus education is caught in a vicious circle from which it can only with great difficulty extricate itself. This problem is of course not peculiar to the schools; it is part of the larger problem of mankind, and, incleed. of the evolutionary process itself. Progress can, in general, take place only through the segregation of the more progressive from the less progressive elements, and the problem is how to achieve this in human society without doing violence to our democratic standards and ideals.

\section{Reproductive Dead-End}

The historian, Arnold Toynbee, takes a pessimistic view of the future of our civilization. According to him, all past civilizations have fallen through the same cause: Creative minorities have lost their creativeness. (The same view was held and ably expounded by John Stuart Mill in his book Liberty, wherein he presented an amazing prophecy of conditions existing in Europe today.) By far the 